\title{
ENVELHECIMENTO E TECNOLOGIA: A CULTURA DO SAPATO NA PORTA
}

Em algumas culturas há o costume de se deixar os sapatos na porta da casa. Isso seria um sinal de cuidado e respeito, símbolo que vai além da higiene. Por outro lado, quando não há este hábito e ele é colocado como imposição de regras, poderá causar desconforto, preconceitos e antipatia. Assim verificamos comportamentos que podem dificultar um envelhecimento ativo em nossa sociedade, pois hábitos estão enraizados e não necessariamente associados à melhora da qualidade de vida. Uma mesma informação poderá causar reações diferentes. A manutenção de uma vida ativa e não somente produtiva após o envelhecimento é um fenômeno recente, cada vez mais aceito em nossa sociedade. No entanto, há demandas individuais que devem ser respeitadas. Eis o desafio para as mudanças de comportamento: nos transformarmos em uma sociedade com alternativas, independente de crenças, condutas e que respeitem as diferenças para melhores índices de qualidade de vida.

Uma feira temática tendo o envelhecimento como pano de fundo foi realizada em Belo Horizonte entre os dias 15 e 17 de outubro de 2015. O objetivo comercial entrelaçado de várias oportunidades de negócio e lazer, com a participação de entidades públicas e privadas, denominado Feira da Longevidade Ativa, apresentou uma experiência ímpar para o público. Seguimentos de turismo, beleza, alimentação, saúde, transporte, academia, residência alternativa, imóveis, tecnologia/informação, educação, moda, instituições financeiras e de crédito, atividades artísticas e gastronomia estiveram presentes no evento. O local, a Serraria Souza Pinto em Belo Horizonte, um prédio centenário, foi reformado em 1997 e está ativo para eventos desta natureza. Bem apropriado neste quesito.

Obtive três depoimentos no evento:

O Sr. Marçal Rezende, 67 anos, participou das oficinas oferecidas, em especial da Oficina de Memória, e disse que havia novidades interessantes. Enfatizou as palestras com as pedagogas em que foi oferecida a oportunidade de troca de experiências com o público e os depoimentos relacionados à importância de atividades remuneratórias após os 70 anos.

A Sra. Jandira, 76 anos, artista e cantora do show de encerramento, criticou a ausência de eventos para o seguimento e disse que havia muito preconceito antes desta feira. Também pontuou que muitos idosos querem ser ativos socialmente e não podem, pois não há suporte social nem opções de atividades.

A Dra. Nara Chimicatti, médica, também disse ser muito válida a iniciativa, ainda que grande parte da sociedade não possa ter acesso a várias tecnologias pelo custo elevado. Os profissionais devem estar cientes das novidades tecnológicas para oferecerem aos indivíduos que necessitam de cuidados especiais, relatou. No seu ponto de vista, a feira trouxe algumas novidades.

Os pontos negativos do evento são comuns à grande parte do Brasil, como dificuldade para acesso ao local devido a dificuldades de transporte, além do clima não estar favorável (muito quente e seco). Houve também uma participação tímida das entidades, especialmente de saúde.

As publicações científicas com inovações e novas tecnologias e sua divulgação ainda são escassas, mas há um crescente interesse e possibilidades que poderiam beneficiar a sociedade. Eventos como esse poderiam estar integrados, inclusive, a congressos da área de saúde.

A parceria entre entidades científicas e eventos com esta iniciativa certamente contribuiriam para dirimir dificuldades e apontar soluções na área da Atenção à Saúde do Idoso no seu aspecto mais amplo, na sua comunidade e na manutenção de sua independência e qualidade de vida.

Eventos como este poderiam iniciar mudanças de comportamento com a participação do público alvo, com quebra de paradigmas, respeitando-se a individualidade tanto quanto a de se achar que o sapato está, apenas, no local onde deveria estar, contribuindo para o bem-estar daquela família.

Fausto Aloísio Pedrosa Pimenta

Professor Adjunto da Escola de Medicina da Universidade Federal de Ouro Preto 